Original

\title{
Absence of DNA Damage in Comet Assay and Liver Initiation Activity of Cinnamaldehyde
}

\author{
Masako Muguruma $^{1}$, Mitsuyoshi Moto ${ }^{1}$, Yu F. Sasaki², Miwa Okamura ${ }^{1}$, \\ Takao Watanabe $^{1}$, Yoko Kashida ${ }^{1}$, and Kunitoshi Mitsumori ${ }^{1}$ \\ ${ }^{1}$ Laboratory of Veterinary Pathology, Faculty of Agriculture, Tokyo University of Agriculture and Technology, \\ 3-5-8 Saiwai-cho, Fuchu-shi, Tokyo 183-8509, Japan \\ ${ }^{2}$ Laboratory of Genotoxicity, Faculty of Chemical and Biological Engineering, Hachinohe National College of \\ Technology, 16-1 Tamonoki, Hachinohe-shi, Aomori 039-1192, Japan
}

\begin{abstract}
To clarify the in vivo genotoxicity of cinnamaldehyde (CNMA) that is present in cigarette smoke, 8 organs and bone marrow of male mice given a single oral administration of 250 or $125 \mathrm{mg} / \mathrm{kg}$ body weight of CNMA were evaluated by an alkaline single-cell gel electrophoresis (comet) assay. The liver initiation activity of CNMA was also investigated by a short-term liver initiation assay. PH (Partially hepatectomized) male rats were given $1250 \mathrm{mg} / \mathrm{kg}$ body weight of CNMA by a single oral administration 12 hours after partial hepatectomy. In the comet assay, no significant differences of nuclear migration were observed in all tissues examined in mice treated with CNMA at 3 and 24 hours after administration. In the initiation assay, there were no significant increases in areas and numbers of glutathione Stransferase placental form (GST-P) positive foci in the livers of rats treated with CNMA. Based on these results, the possibility that CNMA has in vivo genotoxicity or liver initiation activity appears to be extremely low.

(J Toxicol Pathol 2005; 18: 27-31)
\end{abstract}

Key words: cinnamaldehyde, genotoxicity, comet assay, liver initiation assay

\section{Introduction}

Cinnamaldehyde (CNMA, CAS No. 104-55-2), the main component of cinnamon bark oil, has been detected as one of the volatile aldehydes in cigarette smoke ${ }^{1-3}$. CNMA is used in various foods such as beverages, ice-cream, sweets and chewing gum because it has a strong fragrance ${ }^{4}$, and human exposure as a result of these applications has increased. For this reason, careful assessment of CNMA toxicity is required and a number of toxicological studies on CNMA have been performed. In in vivo carcinogenicity studies using mice, it has been shown that CNMA does not have any carcinogenic potential to the lung ${ }^{2,5}$, but it has an inhibiting effect in 4-(methylnitrosamino)-1-(3-pyridyl)-1butanone (NNK)-induced pulmonary carcinogenesis ${ }^{3}$. CNMA induced a clastogenic effect in the liver and forestomach mucosa of rats and mice. It showed a significant increase of gamma-glutamyltranspeptidase foci in the liver of rats initiated with $\mathrm{N}$-nitrosodimethylamine ${ }^{6}$

Received: 27 October 2004, Accepted: 7 February 2005

Mailing address: Masako Muguruma, Laboratory of Veterinary Pathology, Faculty of Agriculture, Tokyo University of Agriculture and Technology, 3-5-8 Saiwai-cho, Fuchu-shi, Tokyo 183-8509, Japan

TEL: 81-42-367-5874 FAX: 81-42-367-5874

E-mail:muguruma@cc.tuat.ac.jp and forestomach hyperplasias in rats and mice when administrated by microencapsulation in feed ${ }^{7}$. Although negative results were obtained in the Ames test using Salmonella strains with or without $\mathrm{S} 9 \mathrm{mix}^{8-10}$ and the SOS chromotest ${ }^{10}$, positive results were reported in the DNA repair test and in vitro genotoxicity studies ${ }^{9,10}$. Based on these background data, there remain some toxicological concerns about the genotoxic and tumor-modifying effects of CNMA in the liver and stomach tumor development.

It has been reported that the comet assay can detect the genotoxicity of chemicals and their metabolites not only in the bone marrow but also in other organs in vivo ${ }^{11}$. The comet assay has shown a high positive response ratio for rodent genotoxic carcinogens and a high negative response ratio for rodent genotoxic non-carcinogens ${ }^{12}$. A mediumterm or short-term liver initiation assay utilizing the induction of GST-P positive liver foci resulting from gene mutations in rats has been developed to identify in vivo genotoxic carcinogens as an alternative to long-term carcinogenicity studies. The expression of GST-P is a useful marker for most hepatocellular preneoplastic and neoplastic lesions ${ }^{13-15}$. Therefore, this initiation assay seems to be a useful method for clarifying whether or not chromosome aberrations and/or gene mutations resulting from DNA damage induced by CNMA cause enhanced GST-P foci.

In the present study, a comet assay in mice and a short- 
term liver initiation assay using rats were performed to clarify the in vivo genotoxic and liver initiating potential of CNMA.

\section{Materials and Methods}

\section{Animals}

Male ddY mice and F344 rats were obtained from Japan SLC Inc. (Shizuoka, Japan) at 8 and 6 weeks of age, respectively, and they were used after 1 week of acclimation. Mice were housed four per polycarbonate cage with white paper chips for bedding and allowed ad libitum access tap water and commercial basal diet $\left(\mathrm{MF}^{\circledR}\right.$, Oriental Yeast Co., Ltd. Tokyo, Japan). Rats were housed three to four per steel cage and given tap water and commercial basal diet ad libitum. All animals used were handled under standard conditions (room temperature, $22 \pm 2{ }^{\circ} \mathrm{C}$; relative humidity, $55 \pm 5 \% ; 12$-h light and dark cycle).

\section{Test substances and chemicals}

The test compound, trans-CNMA (purity, >98\%) was kindly provided by Japan Tobacco Inc. (Tokyo, Japan). Olive oil, carbon tetrachloride $\left(\mathrm{CCl}_{4}\right)$, sodium carboxymethylcellulose (CMC) and 2-acetylaminofluorene (2-AAF) were purchased from Wako Pure Chemical Industries, Ltd. (Osaka, Japan).

\section{Comet assay in mice}

Male ddY mice aged 9 weeks were used for the evaluation of DNA damage by the comet assay. The design of this experiment was basically the same as that of previous comet assay studies on multiple mouse organs ${ }^{12,16,17}$. The oral $\mathrm{LD}_{50}$ of CNMA in mice and rats has been reported to be 2225 to $5000 \mathrm{mg} / \mathrm{kg}$ body weight and 2220 to $3400 \mathrm{mg} / \mathrm{kg}$ body weight, respectively ${ }^{18}$. However, it has been reported that the function of the central nervous system was injured in mice by a single oral administration of CNMA at $500 \mathrm{mg} / \mathrm{kg}$ body weight ${ }^{19}$. Therefore, we regarded the dose of $500 \mathrm{mg} /$ $\mathrm{kg}$ body weight of CNMA as the maximum tolerated dose, and the high and low doses of CNMA in the present study were chosen as $250 \mathrm{mg} / \mathrm{kg}$ body weight (one half of oral MTD) and $125 \mathrm{mg} / \mathrm{kg}$ body weight, respectively. Mice were divided into six groups of 4 mice, and vehicle (olive oil) or CNMA solution was administrated once orally to the animals at a volume of $20 \mathrm{~mL} / \mathrm{kg}$ body weight. Three or 24 hours after administration of CNMA (125 mg/ $\mathrm{kg}$ or $250 \mathrm{mg} /$ $\mathrm{kg}$ body weight) or olive oil as a control, mice were sacrificed and the stomach, colon, liver, kidney, urinary bladder, lung, brain, and bone marrow were removed. The liver, kidney, lung and brain were minced and suspended in $4 \mathrm{~mL}$ of chilled homogenizing solution $(0.075 \mathrm{M} \mathrm{NaCl}$ and $0.024 \mathrm{M} \mathrm{Na}_{2}$ EDTA, $\mathrm{pH} 7.5$ ), then homogenized gently at 500 to $800 \mathrm{rpm}$ on ice. The glandular stomach, colon, and urinary bladder were opened and rinsed with physiological saline; then the mucosa was scraped into $4 \mathrm{~mL}$ of chilled homogenizing buffer and homogenized as described above. To obtain nuclei, the homogenate was centrifuged at $700 \times g$ for $10 \mathrm{~min}$ at $0^{\circ} \mathrm{C}$, and the precipitate was re-suspended in chilled homogenizing buffer at $1 \mathrm{~g}$ organ weight per milliliter. Slides prepared from nuclei isolated by homogenization were placed in a chilled lysing solution $(2.5$ $\mathrm{M} \mathrm{NaCl}, 100 \mathrm{mM} \mathrm{Na}{ }_{2}$ EDTA, $10 \mathrm{mM}$ Tris- $\mathrm{HCl}, 1 \%$ sarkosyl solution, 10\% DMSO, and 1\% Triton X-100, $\mathrm{pH} 10$ ) and kept on ice in the dark for more than $60 \mathrm{~min}$. They were then removed in chilled alkaline solution $(300 \mathrm{mM} \mathrm{NaOH}$ and 1 $\mathrm{mM} \mathrm{Na} \mathrm{N}_{2}$ EDTA, $\mathrm{pH} 13$ ) for $10 \mathrm{~min}$ in the dark on ice. Electrophoresis was conducted at $0^{\circ} \mathrm{C}$ in the dark for $15 \mathrm{~min}$ at $25 \mathrm{~V}(0.96 \mathrm{~V} / \mathrm{cm})$ and approximately $250 \mathrm{~mA}$. The slides were neutralized and thereafter stained with $50 \mu \mathrm{l}$ of $20 \mu \mathrm{g} /$ $\mathrm{mL}$ ethidium bromide. We examined and photographed 50 nuclei per slide at $200 \times$ magnification with the aid of fluorescence microscopy. The migrations as the difference between the whole comet length and the diameter of the head for each were calculated, and the mean migration of 50 nuclei from each organ was calculated for each individual animal.

\section{Liver initiation assay in rats}

The in vivo short-term liver initiation assay was performed according to the method of Tsuda et al. ${ }^{13}$. Since the $\mathrm{LD}_{50}$ by oral administration of CNMA for rats was reported as $2220 \mathrm{mg} / \mathrm{kg}$ body weight ${ }^{18}$, the dose of CNMA was set at $1250 \mathrm{mg} / \mathrm{kg}$ body weight, about one half of the $\mathrm{LD}_{50}$ for rats. CNMA was suspended in $0.5 \% \mathrm{CMC}$ solution at a concentration of $1250 \mathrm{mg} / 20 \mathrm{~mL}$. Male F344 rats, 7 weeks old, were subjected to two-thirds partial hepatectomy (PH) on day 0 . Twelve hours after the completion of surgery, the $\mathrm{PH}$ rats were divided into two groups of 7 rats and treated once orally with $0.5 \%$ of CMC as vehicle or 1250 $\mathrm{mg} / \mathrm{kg}$ body weight of CNMA. Subsequently, the rats were fed the basal diet for 2 weeks, and then a diet containing $0.015 \%$ of 2 -AAF (CLEA Japan, Inc. Osaka, Japan) for the following 2 weeks. Three weeks after CNMA administration, all animals received a single dose of $0.8 \mathrm{~mL} /$ $\mathrm{kg}$ body weight of $\mathrm{CCl}_{4}$. At the end of week 4, the animals were sacrificed under ether anesthesia, and slices of all liver lobes were fixed in 10\% neutral buffered formalin (Fig. 1). These tissues were embedded in paraffin, sectioned, and subjected to immunohistochemical detection of putative preneoplastic foci of hepatocytes that express the enzyme GST-P with anti-GST-P antibody (Medical and Biological Laboratories Co., Ltd. Aichi, Japan). Hematoxylin-eosin (H\&E) staining was routinely performed for microscopic examinations. The areas and numbers of GST-P positive foci ( $>0.1 \mathrm{~mm}$ in diameter) and the total areas of each liver section examined in each animal were measured with a computer-assisted image analyzer, NIH (National Institute of Health) image, then the mean area was calculated and the number of GST-P positive foci per unit area of all the liver sections was examined per animal.

\section{Statistical analysis}

The data obtained from both experiments were expressed as mean $\pm \mathrm{S}$.E. In the comet assay, the 


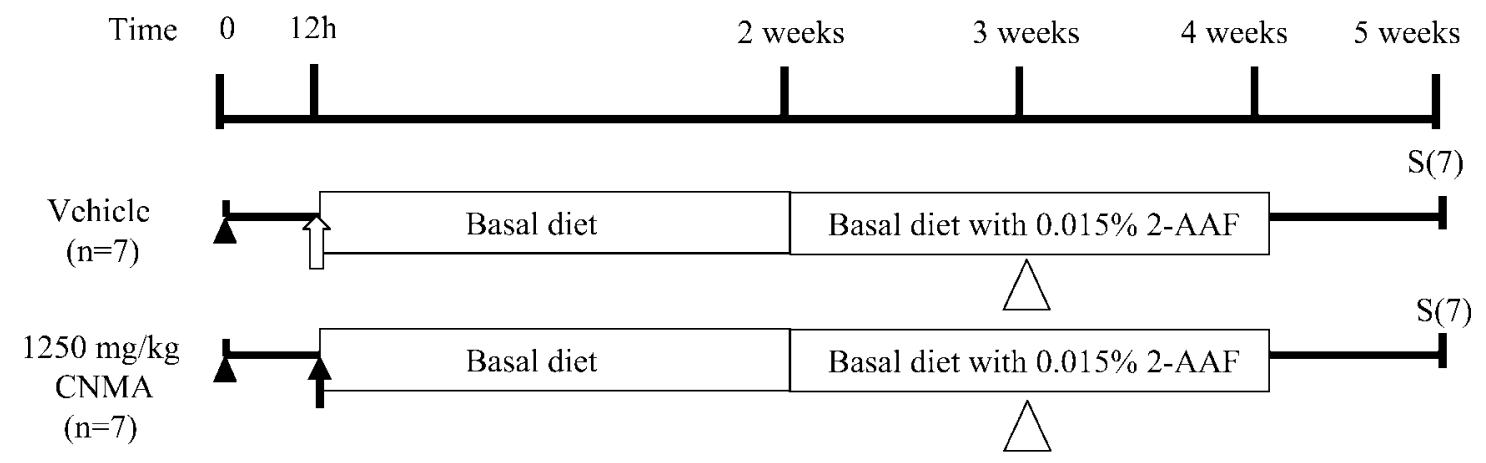

Fig. 1. Experimental design for liver initiation assay in male F344 rats. $\boldsymbol{\Delta}$ : Two-thirds partial hepatectomy. $\}$ : Administration of $0.5 \%$ of CMC. $\mathbf{\uparrow}$ : Administration of $1250 \mathrm{mg} / \mathrm{kg}$ body weight of CNMA. $\triangle$ : Administration of $0.8 \mathrm{~mL} / \mathrm{kg}$ body weight of $\mathrm{CCl}_{4}$. S(n): Sacrifice (n)

Table 1. Migration of Nuclear DNA from Organs of Mice Treated with CNMA by Single Gavage Dosing

\begin{tabular}{|c|c|c|c|c|c|c|c|c|c|c|c|}
\hline \multirow[b]{2}{*}{ Group } & \multirow{2}{*}{$\begin{array}{c}\text { Dose } \\
(\mathrm{mg} / \mathrm{kg})\end{array}$} & \multirow{2}{*}{$\begin{array}{l}\text { Number of } \\
\text { animals }\end{array}$} & \multirow{2}{*}{$\begin{array}{l}\text { Sampling } \\
\text { time (hrs) }\end{array}$} & \multicolumn{8}{|c|}{ Migration (mm) } \\
\hline & & & & Stomach & Colon & Liver & Kidney & Bladder & Lung & Brain & Bone marrow \\
\hline $\begin{array}{l}\text { Control } \\
\text { (vehicle) }\end{array}$ & 0 & 4 & 3 & $6.07 \pm 0.73$ & $4.72 \pm 0.24$ & $2.37 \pm 0.38$ & $1.60 \pm 0.46$ & $4.23 \pm 0.66$ & $2.74 \pm 0.36$ & $1.14 \pm 0.46$ & $\begin{array}{ll}6 & 1.58 \pm 0.73\end{array}$ \\
\hline \multirow[t]{2}{*}{ CNMA } & 250 & 4 & 3 & $\overline{5} . \overline{55} \pm \overline{0.60}$ & $4 . \overline{80} \pm \overline{0.30}$ & $2 . \overline{40} \pm 0 . \overline{87}$ & $\overline{1.47 \pm 0 . \overline{24}}$ & $\overline{4.98 \pm} \pm 0.33$ & $3 . \overline{8} \pm \overline{0.37}$ & $2 . \overline{32} \pm \overline{0.65}$ & $\begin{array}{cc}5 & 0 . \overline{9} 1 \pm 0.34\end{array}$ \\
\hline & 500 & 4 & 3 & $6.72 \pm 0.34$ & $4.49 \pm 0.56$ & $2.28 \pm 0.62$ & $1.72 \pm$ & $5.89 \pm 0.63$ & $2.62 \pm 0.26$ & $1.99 \pm 0.54$ & $1.31 \pm 0.09$ \\
\hline $\begin{array}{l}\text { Control } \\
\text { (vehicle) }\end{array}$ & 0 & 4 & 24 & $6.24 \pm 0.48$ & $5.49 \pm 0.59$ & $2.19 \pm 0.35$ & $1.96 \pm 0.17$ & $3.72 \pm 0.58$ & $2.12 \pm 0.46$ & $1.34 \pm 0.45$ & $1.09 \pm 0.37$ \\
\hline \multirow[t]{2}{*}{ CNMA } & 250 & 4 & 24 & $5.71 \pm 0.80$ & $4.83 \pm 0.67$ & $3.23 \pm 0.65$ & $1.03 \pm 0.68$ & $3.82 \pm 0.93$ & $3.23 \pm 1.02$ & $2.68 \pm 0.33$ & $1.60 \pm 0.63$ \\
\hline & 500 & 4 & 24 & $3.73 \pm 1.18$ & $4.63 \pm 0.52$ & $2.42 \pm 0.30$ & $2.22 \pm 0.45$ & $6.01 \pm 1.11$ & $2.90 \pm 0.40$ & $2.73 \pm 0.66$ & $5 \quad 1.88 \pm 0.69$ \\
\hline
\end{tabular}

Mice were sacrificed 3 and 24 hours after a single administration of CNMA

Values are the mean \pm S.E. of 4 animals.

significance of the differences between the vehicle group and each CNMA group for each sampling time were determined by Dunnett's test after one-way ANOVA. For the initiation assay, the significance of difference between the control group and the CNMA group was determined by Student's $t$-test. A $p$-value less than 0.05 was considered statistically significant in both analyses.

\section{Results and Discussion}

In the comet assay, no death, morbidity, or clinical signs were observed in vehicle and CNMA treated mice during the experimental period. In CNMA groups, the induction of comets having well separated heads and tails was not observed in any of the organs examined at 3 and 24 hours after administration. The vehicle group, like the CNMA groups did not show any significant nuclei migration in any of the organs examined at 3 and 24 hours after the administration (Table 1).

In previous in vivo genotoxicity studies using rodent species, it has been reported that CNMA administrated by oral gavage in a single dose of $1100 \mathrm{mg} / \mathrm{kg}$ equal to $1 / 2 \mathrm{LD}_{50}$ did not produce any statistically significant increase of DNA fragmentation in the rat liver or gastric mucosa ${ }^{6}$. Mirsalis $e t$ al., have reported that CNMA has no in vivo genotoxicity in rat and mouse hepatocytes in unscheduled DNA synthesis tests $^{20}$. Hayashi et al., have also reported that CNMA has no in vivo genotoxicity for mouse bone marrow cells in a micronucleus assay ${ }^{21,22}$. In toxicokinetic studies, the maximum concentration of CNMA in the blood of F344 male rats was found in samples taken at 6.5 hours after a single dose administration of $500 \mathrm{mg} / \mathrm{kg}$ body weight, and more than $99 \%$ of the total dose of radio-labeled CNMA was eliminated within 24 hours after a single dose administration ${ }^{23}$. The result of that toxicokinetic study suggests that mice given $250 \mathrm{mg} / \mathrm{kg}$ body weight were sufficiently exposed to CNMA in our present study, the results of which are in agreement with the negative results of the previous genetoxicity studies described above.

In the short-term liver initiation assay, no death, morbidity, or clinical signs were observed in vehicle and CNMA-treated animals during the experimental period. In histopathological examinations, there were no remarkable changes found between the vehicle and CNMA groups in any of the sections. Representative rat liver foci of $\mathrm{H} \& \mathrm{E}$ and GST-P immunohistochemical stainings in rats subjected to 
the treatment of 2 -AAF and $\mathrm{CCl}_{4}$ after a single administration of $1250 \mathrm{mg} / \mathrm{kg}$ CNMA are shown in Figs. 2A and $2 \mathrm{~B}$, respectively. No significant differences were observed in the mean area and number of GST-P positive foci between the vehicle (number, $15.0 \pm 6.9 \mathrm{cells} / \mathrm{cm}^{2}$; area, $1.5 \pm 0.8 \mathrm{~mm}^{2} / \mathrm{cm}^{2}$ ) and CNMA group (number, $16.3 \pm 4.4$ cells $/ \mathrm{cm}^{2}$; area, $2.1 \pm 1.0 \mathrm{~mm}^{2} / \mathrm{cm}^{2}$ ) (Fig. 2C). In a previous short-term carcinogenicity study using strain A mice, i.p. injections of CNMA were given 3 times per week for 8 weeks ( $4 \mathrm{~g} / \mathrm{kg}$ mouse as total dose) and mice were sacrificed at 24 weeks after the first injection. There was no increase in the incidence of lung tumors in the treated mice ${ }^{5}$. Mereto et al., reported that an increase in the incidence and size of GGT-positive foci in hepatocytes was observed in rats initiated with N-nitrosodiethylamine, then treated with CNMA by gavage for 14 days. Based on these results, they concluded that CNMA could act as a weak promoter of the liver carcinogenesis ${ }^{6}$. In contrast, in our previous study, rasH2 mice were initiated with urethane for 2 weeks followed by diet containing $0.5 \%$ CNMA for 26 weeks, there were no significant inter-group differences in the incidence and multiplicities of alveolar/bronchiolar hyperplasias and adenomas $^{2}$. In another of our previous reports, rasH2 mice were initiated with 4-(methylnitrosamino)-1-(3-pyridyl)-1butanone (NKK) once a week for 2 weeks followed by diet containing $0.5 \%$ CNMA for 26 weeks, and CNMA treatment significantly reduced the combined incidence of lung adenomas and carcinomas, as well as multiplicity of NKKinduced lung tumors in male rasH2 mice. These results suggest that CNMA has the potential to promote the development of carcinogen-initiated liver tumorigenesis or inhibit lung tumorigenesis in rats and mice ${ }^{3}$. There are a few reports of in vitro experiments on cell growth inhibition and induction of apoptosis in cancer cell lines treated with $\mathrm{CNMA}^{25,26}$. In the present study, we did not find any morphological evidence suggestive of apoptosis, therefore, taking into account the ability of CNMA to induce apoptosis, we consider the tumor promoting effect of CNMA to be very weak.

Recently, the National Toxicology Program (NTP) of the United States of America has reported that there was no evidence of carcinogenicity of trans-CNMA in male or female $\mathrm{F} 344 / \mathrm{N}$ rats and $\mathrm{B} 6 \mathrm{C} 3 \mathrm{~F} 1$ mice that were exposed to 1000,2100 , or $4100 \mathrm{ppm}$ trans-CNMA in 2-year feeding studies $^{27}$. In addition, in a recent publication of the Flavor and Extract Manufactures Association (FEMA) ${ }^{28}$, it was concluded that cinnamyl alcohol and related compounds including CNMA lack direct in vivo genotoxicity based on an extensive literature survey. The results of the comet assay in our present study also support the conclusion of FEMA, and confirmed that even if DNA damage is induced by CNMA, it does not result in initiating activity in the liver.

Acknowledgments: This work was supported by a Grantin-Aid from the Smoking Research Foundation of Japan.
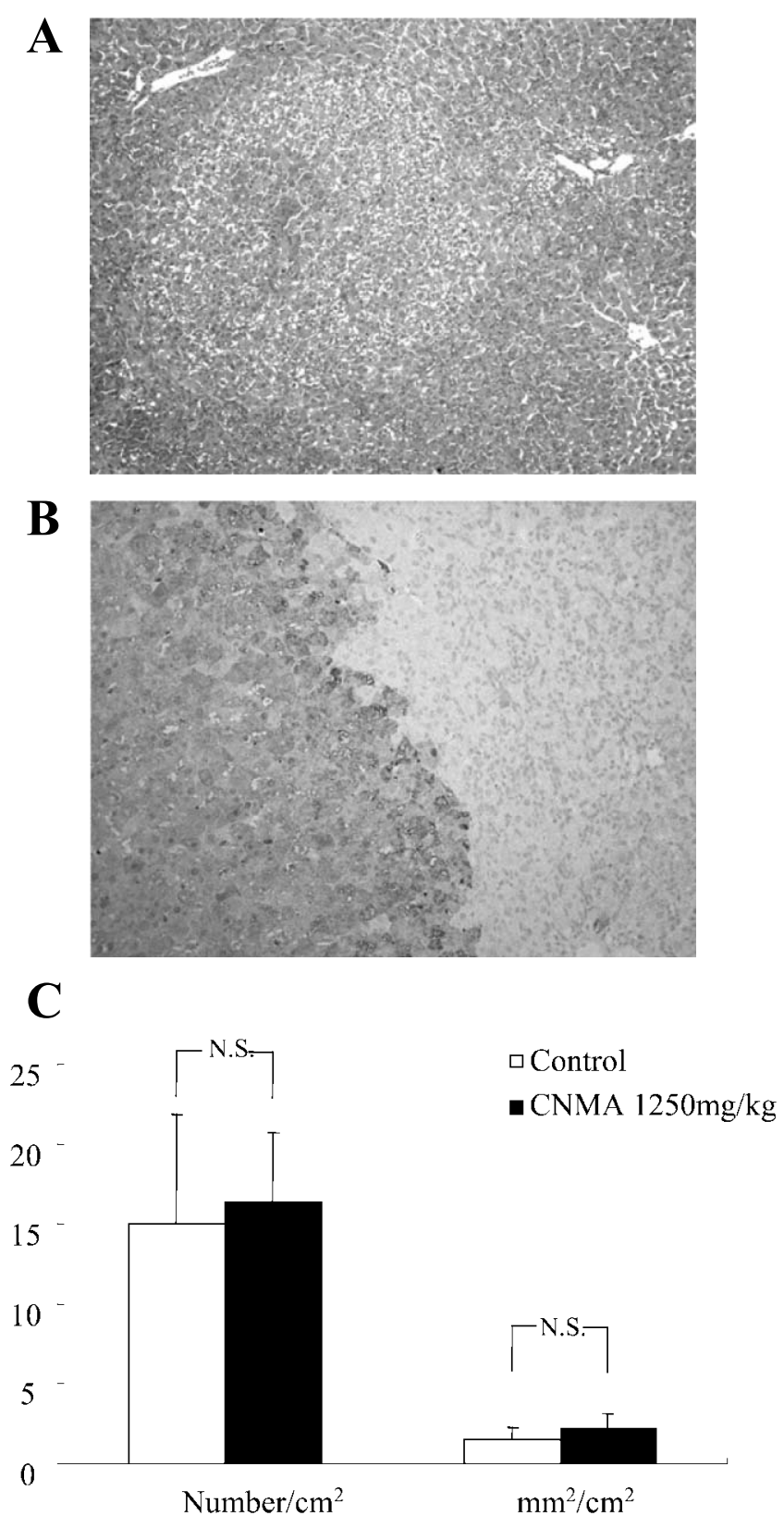

Fig. 2. Representative rat liver focus stained with $H \& E$ (A) and GST$\mathrm{P}$ positive foci in a rat subjected to the treatment of 2-AAF and $\mathrm{CCl}_{4}$ after a single oral dose of $1250 \mathrm{mg} / \mathrm{kg}$ CNMA (B). Number and area/ $\mathrm{cm}^{2}$ of GST-P positive foci in rat liver given CNMA in a liver initiating assay (C). Data are the mean \pm S.E. of 7 animals. N.S.; No significant differences.

\section{References}

1. Demole D and Berther D. A chemical study of burly tobacco flavor (Nicotiana tabacum L.) 1. Volatile to medium-volatile constituents. Helv Chem Acta. 55: 1866-1882. 1972.

2. Tamura T, Yasuhara K, Koujitani T, Onodera H, Takagi H, Takizawa T, Hirose M, Hayashi Y, and Mitsumori K. Lack of modifying effects of cinnamaldehyde on development of lung proliferative lesions induced by urethane in transgenic 
mice carrying the human prototype c-Ha-ras gene. J Toxicol Pathol. 13: 249-255. 2000.

3. Imai $\mathrm{T}$, Yasuhara $\mathrm{K}$, Tamura $\mathrm{T}$, Takizawa $\mathrm{T}$, Ueda $\mathrm{M}$, Hirose M, and Mitsumori K. Inhibitory effects of cinnamaldhyde on 4-(methylnitrosamino)-1-(3-pyridyl)-1butanone -induced lung carcinogenesis in rasH2 mice. Cancer Lett. 175: 9-16. 2002.

4. Opdyke DLJ. Monographs on fragrance raw materials, Cinnamaldehyde. Food Cosmet Toxicol. 19: 253-258. 1979.

5. Stoner GD, Shimkin MB, Kniazeff AJ, Weisburger JH, Weisburger EK, and Gori GB. Test for carcinogenicity of food additives and chemotherapeutic agents by the pulmonary tumor response in strain A mice. Cancer Res. 33: 3069-3085. 1973.

6. Mereto E, Brambilla-Campart G, Ghia M, Martelli A, and Brambilla G. Cinnamaldehyde-induced micronuclei in rodent liver. Mutat Res. 322: 1-8. 1994.

7. Hebert CD, Yuan J, and Dieter MP. Comparison of the toxicity of cinnamaldehyde when administered by microencapsulation in feed or by corn oil gavage. Food Chem Toxicol. 32: 1107-1115. 1994.

8. Kasamaki A, Takahashi H, Tsumura N, Niwa J, Fujita T, and Urasawa S. Genotoxicity of flavoring agents. Mutat Res. 105: 387-392. 1982.

9. Sekizawa J and Shibamoto T. Genotoxicity of safrole-related chemicals in microbial test systems. Mutat Res. 101: 127140. 1982.

10. Stammati A, Bonsi P, Zucco F, Moezelaar R, Alakomi HL, and von Wright A. Toxicity of selected plant volatiles in microbial and mammalian short-term assays. Food Chem Toxicol. 37: 813-823. 1999.

11. Sasaki YF, Tsuda S, Izumiyama F, and Nishidate E. Detection of chemically induced DNA lesions in multiple mouse organs (liver, lung, spleen, kidney and bone marrow) using the alkaline single cell gel electrophoresis (Comet) assay. Mutat Res. 388: 33-44. 1997.

12. Sasaki YF, Sekihashi K, Izumiyama F, Nishidate E, Saga A, Ishida $\mathrm{K}$, and Tsuda $\mathrm{S}$. The comet assay with multiple mouse organs: comparison of comet assay results and carcinogenicity with 208 chemicals selected from the IARC monographs and U.S. NTP Carcinogenicity Database. Crit Rev Toxicol. 30: 629-799. 2000.

13. Tsuda H, Lee G, and Farber E. Induction of resistant hepatocytes as a new principle for a possible short-term in vivo test for carcinogens. Cancer Res. 40: 1157-1164. 1980.

14. Ito N, Imaida K, Tsuda H, Shibata M, Aoki T, de Camargo JL, and Fukushima S. Wide-spectrum initiation models: possible applications to medium-term multiple organ bioassays for carcinogenesis modifiers. Jpn J Cancer Res. 79: 413-417. 1988.

15. Sakai H, Tsukamoto T, Yamamoto M, Kobayashi K, Yuasa H, Imai T, Yanai T, Masegi T, and Tatematsu M. Distinction of carcinogens from mutagens by induction of liver cell foci in a model for detection of initiation activity. Cancer Lett. 188: 33-38. 2002.

16. Tice RR, Agurell E, Anderson D, Burlinson B, Hartmann A, Kobayashi H, Miyamae Y, Rojas E, Ryu JC, and Sasaki YF. Single cell gel/comet assay: guidelines for in vitro and in vivo genetic toxicology testing. Environ Mol Mutagen. 35: 206-221. 2000.

17. Moto M, Sasaki YF, Okamura M, Fujita M, Kashida Y, Machida N, and Mitsumori K. Absence of in vivo genotoxicity and liver initiation activity of dicyclanil. J Toxicol Sci. 28: 173-179. 2003.

18. Harada M and Ozaki Y. Pharmacological studies on chinese cinnamaon. I. Central effects of cinnamaldehyde. Yakugaku Zasshi. 92: 135-140. 1972 (in Japanese).

19. Jenner PM, Hagan EC, Tylor JM, Cook EL, and Fitzhugh OG. Food flavourings and compounds of related structure. I. Acute oral toxicity. Food Cosmet Toxicol. 2: 327-343. 1964.

20. Mirsalis JC, Tyson CK, Steinmetz KL, Loh EK, Hamilton CM, Bakke JP, and Spalding JW. Measurement of unscheduled DNA synthesis and S-phase synthesis in rodent hepatocytes following in vivo treatment: testing of 24 compounds. Environ Mol Mutagen. 14: 155-164. 1989.

21. Hayashi M, Sofuni T, and Ishidate M Jr. A pilot experiment for the micronucleus test. The multi-sampling at multi-dose levels method. Mutat Res. 141: 165-169. 1984.

22. Hayashi M, Kishi $M$, Sofuni $T$, and Ishidate $M$ Jr. Micronucleus tests in mice on 39 food additives and eight miscellaneous chemicals. Food Chem Toxicol. 26: 487-500. 1988.

23. National toxicological Program (NTP). Toxicology and Cacinogenesis studies of trans-Cinnamaldehyde (Microencapsulated). Draft NTP TR-514. NIH publication No. 02-4448. 2002.

24. Sapienza PP, Ikeda GJ, Warr PI, Plummer SL, Dailey RE, and Lin CS. Tissue distribution and excretion of ${ }^{14} \mathrm{C}$-labeled cinnamic aldehyde following single and multiple oral administration in male Fischer 344 rats. Food Chem Toxicol. 31: 253-261. 1993.

25. Hagan EC, Hansen WH, Fitzhugh OG, Jenner PM, Jones, WI, Taylor JM, Long EL, Nelson AA, and Brouwer JB. Food flavouring and compounds of related structure. II. Subacute and chronic toxicity. Food Cosmet Toxicol. 5: 141-157. 1967.

26. National Toxicology Program. NTP toxicology and carcinogenesis studies of trans-cinnamaaldehyde (CAS No.14371-10-9) in F344/N rats and B6C3F1 mice (feed studies). Natl Toxicol Program Tech Rep Ser. 514: 1-281. 2004.

27. Adams TB, Cohen SM, Doull J, Feron VJ, Goodman JI, Marnett LJ, Munro IC, Portoghese PS, Smith RL, Waddell WJ, and Wagner BM. The FEMA GRAS assessment of cinnamyl derivatives used as flavor ingredients. Food Chem Toxicol. 42: 157-185. 2004.

28. Stammati A, Bonsi P, Zucco F, Moezelaar R, Alakomi HL, and von Wright A. Toxicity of selected plant volatiles in microbial and mammalian short-term assays. Food Chem Toxicol. 37: 813-823. 1999.

29. Ka H, Park HJ, Jung HJ, Choi JW, Cho KS, Ha J, and Lee KT. Cinnamaldehyde induces apoptosis by ROS-mediated mitochondrial permeability transition in human promyelocytic leukemia HL-60 cells. Cancer Lett. 196: 143152. 2003. 